\title{
ARTE Y DEVOCIÓN EN TORNO A LA MUERTE. LAS COFRADÍAS DE ÁNIMAS DE LOS REALEJOS*
}

\author{
Pablo Hernández Abreu
}

\section{RESUMEN}

Las cofradías de ánimas de las dos principales parroquias de Los Realejos han marcado el devenir de sus templos. Sus imponentes cuadros de ánimas, retablos e imágenes asociadas a ellos han marcado la vida parroquial durante siglos. La fundación de ambas confraternidades, a partir de una idea después de la muerte y del culto a las almas que se encontraban en el purgatorio para poder alcanzar la gloria, es el origen de estos cultos. Además, su crecimiento patrimonial, en el caso del Realejo Alto mayor que en Realejo Bajo, acabaría por dotar a ambas parroquias de una importante fuente patrimonial hasta su desaparición durante los siglos XIX y xx, quedando los vestigios que hoy conservamos en la parroquia de Santiago y que el fuego arrasó en el caso de la parroquia de la Concepción.

Palabras Clave: cofradía, ánimas, culto, san Miguel, cuadro de ánimas, retablo, purgatorio.

ART AND DEVOTION AROUND DEATH.

THE BROTHERHOOD OF SOULS OF LOS REALEJOS

\section{Abstract}

The brotherhoods of souls of parishes of Los Realejos they have marked the history of their temples. His imposing paintings of souls, altarpieces, and sculptures have marked the parish life for centuries. The fundation of both brotherghoods, from a idea after death and the cult of souls of Purgatory to be able to achieve glory is the origin of these cults. In addition, its patrimonial growth, in the case of Realejo Alto is greater than Realejo Bajo, it would end up giving both parishes until their disappearance during the century 19th and 20th, remaining the vestiges that today we conserve in de parish of Santiago and that the fire burned in the parish of the Conception.

KeYwords: brotherhood, souls, worship, san Miguel, paintings of souls, altarpieces, Purgatory. 
La idea de lo fugaz, la vista de esta vida como un mero tránsito, el deber de prepararnos durante nuestro paso por este mundo para la vida eterna es un hecho que siempre ha condicionado la existencia humana. Más si cabe en siglos pasados, cuando la muerte estaba marcada a fuego en la vida cotidiana de una sociedad que en su mayoría veía ese tránsito desde un punto de vista religioso. Desde los inicios del cristianismo en Roma, ya los fieles se reunían en las catacumbas donde reposaban los restos de sus seres queridos para orar por ellos con el fin de que pudieran alcanzar la vida eterna ${ }^{1}$; por lo tanto, a lo largo de la existencia terrenal el personaje debería cumplir con unas expectativas que Dios tenía puestas en él, cargadas de buenas obras que no solo allanaran el camino de la salvación, sino también que ayudaran a los ya difuntos a aliviar su penas y acortar lo máximo posible su estancia en el purgatorio mediante el sufragio de misas que sus descendientes debían encargar. El purgatorio, según la tradición cristiana, es el lugar donde las almas que ya están en gracia de Dios, es decir, que habían hecho méritos durante su vida mortal para alcanzar la gloria de la eternidad, se purifican de los pecados que pudieron cometer. La estancia en él dependerá, en cierto modo, de los sufragios que se les ofrezcan en los ritos religiosos: cuantos más sufragios en honor del difunto se ofrezcan, menor será su estancia en el purgatorio. La manera de representarlo, al ser un lugar que nadie ha visto y del que no hay referencias directas en los textos sagrados, ha dado cierta libertad a los artistas para describirlo, no siendo hasta la celebración de algunos concilios cuando se instituyen algunas bases de su iconografía. Después de establecer su existencia, algunos autores han imaginado a sus integrantes, llegando a representar una serie de seres o monstruos que lo habitan de forma permanente y que se encargan de atormentar a las almas mientras purgan sus pecados.

Ese temor a la muerte y a una estancia prolongada en el purgatorio hacía que a lo largo de los siglos, la mayoría de los fieles que otorgaban testamento ante notario se preocuparan en encargar una serie de misas por su eterno descanso, procurando siempre conseguir la intercesión de aquella imagen de la Virgen, santo o santa a la que tenía especial devoción, diciéndolas en el altar de esas tallas a las que veneraban de forma especial. Así, dejando una suma de dinero para la aplicación de estas eucaristías o responsos, se garantizaban esa ayuda extra para alcanzar la gloria celestial en el menor tiempo posible. Existían también las misas gregorianas, que son unas celebraciones que se aplicaban al difunto durante un mes, y que obtienen su nombre del papa san Gregorio Magno, quien tuvo una revelación por la que un religioso había pasado del purgatorio al cielo gracias a las celebraciones que se habían aplicado por su eterno descanso durante treinta días consecutivos.

* Abreviaturas utilizadas: AHDLL=Archivo Histórico Diocesano de La Laguna; FPASRA= Fondo Parroquia Apóstol Santiago de Realejo Alto; FPCRB = Fondo Parroquia de la Concepción Realejo Bajo; FPSJB = Fondo Parroquia San Juan Bautista de San Juan de la Rambla; FPSU = Fondo Parroquia de Santa Úrsula, Santa Úrsula.

1 Zambrano González, Joaquín: «Ánimas benditas del Purgatorio. Culto, cofradías y manifestaciones artísticas en la provincia de Granada», en El mundo de los difuntos: Culto, cofradías y tradiciones, San Lorenzo del Escorial, Madrid, 2014, pp. 1071-1088. 
En este contexto de mentalidad nobiliaria y de temor de Dios existente, corroborado con lo aprobado en el Concilio Lowitiense (1556), en el que se establece que a través del sacrificio de las misas, oraciones, responsos y otras buenas obras se liberaban las almas del purgatorio, surge en el Seiscientos canario el afán por crear, en las diferentes parroquias, cofradías que se dedicaran a dar culto a esas almas, como medio para garantizar su corta estancia en este espacio previo a la vida eterna, donde el alma del difunto debía purificarse de los pecados cometidos durante su vida mortal, así como garantizar el rezo por las almas de las que nadie se acordaba, ayudándolas también a salir rápidamente del purgatorio. Estas instituciones contaban también con el beneplácito de los beneficiados, ya que la Iglesia defendió la creencia en el purgatorio frente a los postulados protestantes que lo negaban desde la reforma de Martín Lutero ${ }^{2}$. Las cofradías de ánimas garantizaban de algún modo que este culto no se perdiera, actuando en cierta forma como cofradías de misericordia en lo que se refiere al sufrago de entierros de fieles de bajo poder adquisitivo, marginados, enfermos o forasteros, que nadie reclamaba.

\section{FUNDACIÓN}

En las dos parroquias principales de Los Realejos, la parroquia del Apóstol Santiago y la de Nuestra Señora de la Concepción, existieron sendas cofradías, siendo la del antiguo Realejo de Arriba la que más se perpetuó en el tiempo y la que llevó la hegemonía en cuanto a caudal y nivel de culto.

Los primeros datos que tenemos de la confraternidad en la parroquia jacobea son del mes de noviembre de 1584 con la visita pastoral del obispo Fernando de Rueda, cuando dice que tomó razón de la institución de la cofradía "y de lo que se hace y los bienes que tiene» ${ }^{3}$. Sin embargo, se cita un mayordomo anterior, por lo que estaría constituida desde unos años antes aunque no había sido ratificada por el obispo debido a que no se había producido ninguna visita pastoral. De ahí que el prelado pidiera «el libro de visitas de dicha cofradía y la orden que tienen» para ejercer como tal, a lo que ellos contestaron que:

Hasta hoy ningún prelado ni visitador ha visitado dicha cofradía ni tienen libro de visitas, que lo que han guardado es que por el día de San Miguel se junta ellos y el pueblo y toman cuenta a los que han sido mayordomos y eligen otros ${ }^{4}$.

El obispo ordena entonces que:

De aquí en adelante se tomen las cuentas que se han de sumar por los mayordomos de la dicha cofradía cada un año. Que el primer domingo después de celebrar la

2 Estarriol Jiménez, Juana: La pintura de Cuadros de Ánimas en Tenerife, Las Palmas de Gran Canaria, 1981, p. 9.

3 AHDLL, FPASRA, libro 4 de la cofradía de ánimas, p. 5.

${ }^{4}$ FPASRA, libro 4 de la cofradía de ánimas, p. 5. 
fiesta de la cofradía se junten a cabildo y se nombren los hermanos de la dicha cofradía y con ellos el beneficiado de este lugar o el cura que en su ausencia sirviera 5 .

Mientras, en la parroquia de la Concepción del Realejo Bajo existió una cofradía de ánimas desde al menos 1626, que es la fecha en la que comienza el libro de cuentas conservado en el Archivo Diocesano de La Laguna ${ }^{6}$. Sin embargo, si leemos con detenimiento las primeras frases, nos damos cuenta de que se hace referencia a un libro anterior, desde entonces desaparecido, y también a la presentación por parte del mayordomo de las cuentas de años pasados, por lo que estamos ante una fecha de fundación anterior que podría ser comienzos del siglo XVII, posterior a la fecha de 1605, cuando se produce la visita del obispo Francisco Martínez que tasa los oficios de difuntos. Suponemos que si en esa fecha existiera ya la institución, habría quedado reflejada en los mandatos. Al igual que sucede en el caso de la parroquia del Apóstol Santiago, la falta de documentación no nos permite fijar una fecha con exactitud de erección en ambas parroquias.

\section{AJUAR PARA EL CULTO}

Sea como fuere, el comienzo de las confraternidades viene a dotar a los templos de un culto a las ánimas del purgatorio que es verdaderamente importante en el ciclo litúrgico de las parroquias, por lo tanto, los primeros ańos de ambas instituciones, además de los cultos propios que celebraban, los mayordomos se van a encargar de buscar piezas para enriquecer el ajuar de las hermandades. Uno de los primeros gastos que se afrontan es el de encargar un distintivo para la cofradía. En el caso de la parroquia del Apóstol Santiago, desde 1601 aparece reflejada en sus cuentas la compra de "un pendón que se hizo para la dicha cofradía de tafetán colorado gualda con sus flecos, cordones y borlas de seda»' . En el caso de la Concepción, no es hasta la década de los cincuenta del siglo xvil cuando se descargan "cuatrocientos treinta y dos reales por valor de un pendón de damasco amarillo" ${ }^{8}$. Como vemos, no había una uniformidad en cuanto al distintivo de las cofradías de ánimas. En Realejo Alto el distintivo era de color rojo mientras que en Realejo Bajo primaba el amarillo. Si nos fijamos en otras parroquias, en San Juan de la Rambla, por ejemplo, el color del pendón era verde ${ }^{9}$, por lo que no quedó establecido un patrón fijo ni color como distintivo para las instituciones, sino que cada una escogía el color según su criterio.

Desde muy antiguo, la figura de san Miguel Arcángel ha estado ligado al purgatorio junto a la Virgen del Carmen, salvadora de almas según prometió a san Simón Stock. El arcángel pesaba en una balanza las obras buenas y malas que el

5 FPASRA, libro 4 de la cofradía de ánimas, p. 5 v.

${ }^{6}$ AHDLL, FPCRB, libro 15 de la cofradía de ánimas, p. 1.

${ }^{7}$ FRASRA, libro 4 de la cofradía de ánimas, p. 19.

${ }^{8}$ FPCRB, libro 15 de la cofradía de ánimas, p. 18.

9 AHDLL, FPSJB, libro 8 de la cofradía de ánimas, p. 10. 


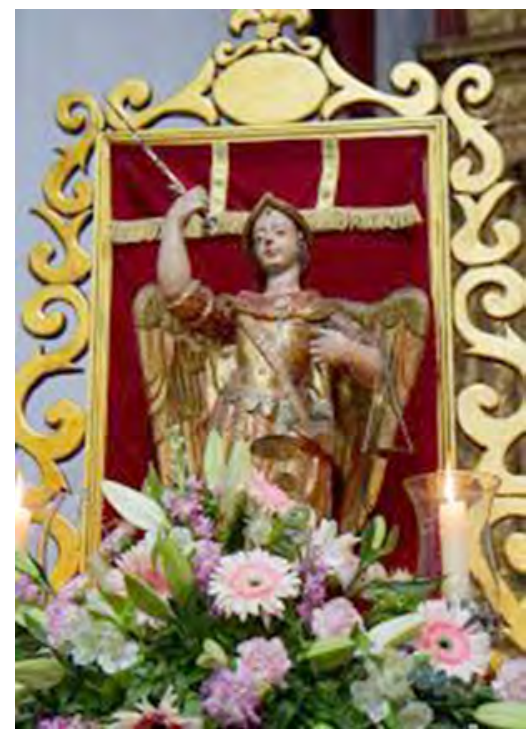

Fig. 1. San Miguel Arcángel. Anónimo tinerfeño, anterior a 1610, parroquia del Apóstol Santiago, Los Realejos.

difunto había realizado durante su vida mortal, y ese resultado equilibraba su viaje hacia la gloria celestial o hacia las penas del infierno. En el caso de la parroquia del Apóstol Santiago, es en 1601 cuando deciden comenzar a celebrar la fiesta de San Miguel Arcángel «por las ánimas del purgatorio de los dichos cofrades como es costumbre en todas partes $»^{10}$, haciéndole posteriormente, en 1605 , unas andas procesionales ${ }^{11}$, aunque hay constancia de que se reunían para elegir mayordomo en la fiesta del santo al menos desde $1584^{12}$. Por la falta de documentación relativa a la cofradía, no hay constancia de la compra de una imagen de san Miguel Arcángel a finales del siglo XVI, por lo que suponemos que comienzan a realizar la función con una talla existente en la parroquia desde esa centuria y que adscriben al patrimonio de la cofradía, tal y como consta en el inventario del mes de agosto de $1604^{13}$. Posteriormente, se produce un descargo de "cuatrocientos y sesenta reales que costó la hechura del señor San Miguel que trajeron y está en dicha iglesia» antes de $1610^{14}$. La obra, de pequeño formato, es salida de talleres tinerfeńos aunque con reformas posteriores, por lo que es complicado hacer una atribución acertada [fig. 1].

${ }^{10}$ FPASRA, libro 4 de la cofradía de ánimas, p. 17v.

11 FPASRA, libro 4 de la cofradía de ánimas, p. 19.

${ }^{12}$ FPASRA, libro 4 de la cofradía de ánimas, p. 5.

13 FPASRA, libro 4 de la cofradía de ánimas, p. 7v.

14 FPASRA, libro 4 de la cofradía de ánimas, p. 11v. 


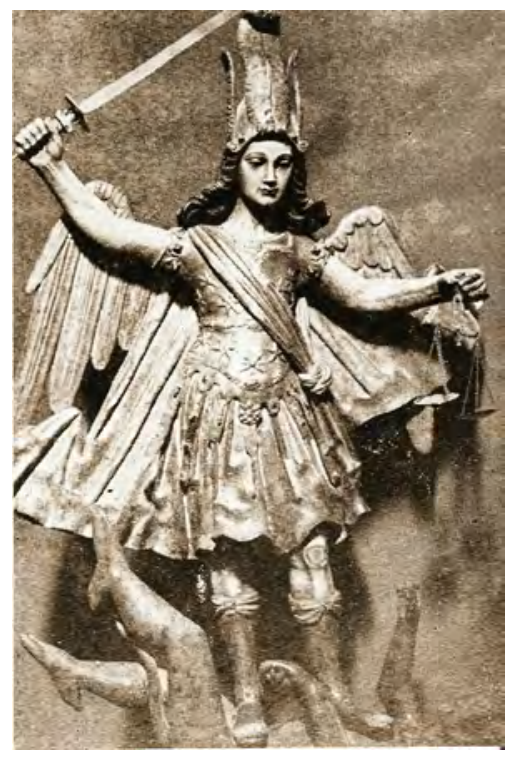

Fig. 2. San Miguel Arcángel (desaparecido). Anónimo tinerfeño, 1650-1660, parroquia de Nuestra Señora de la Concepción, Los Realejos.

En el caso de la parroquia de Nuestra Señora de la Concepción, no sería hasta el período de mayordomía del presbítero Salvador de Aguiar, entre 1651 y 1662, cuando se adquiere una imagen de san Miguel Arcángel por valor de ciento un reales ${ }^{15}$, que estuvo situada hasta el incendio de 1978 en una hornacina en la predela del propio retablo [fig. 2]. La propia obra está representada con la balanza para pesar las almas en su mano izquierda, mientras en la derecha levanta la espada para acabar con el demonio, que se encuentra bajo sus pies. Sin embargo, la compra de unas pesas más de un siglo después, en 1779, nos lleva a pensar que en su origen la imagen llevaba atada a su mano la cabeza del demonio, como suele ocurrir en las distintas representaciones que se dan en la centuria ${ }^{16}$. La talla, de delicado trabajo y rico estofado, poseía un ligero movimiento del cuerpo, a la vez que sus ropajes demostraban cierta tosquedad a la hora de representar el movimiento. A través de una sola fotografía es difícil arriesgarnos en una autoría determinada, más si cabe aún al ser en blanco y negro, ya que no podemos comprobar los colores utilizados en los ropajes para asemejarlos con otros de similar factura y cronología. La no referencia en las cuentas a haberla "traído" nos descarta una procedencia foránea, algo que corroboramos por el análisis formal de la obra. Dentro de la cautela antes

15 FPCRB, libro 15 de la cofradía de ánimas, p. 16.

16 FPCRB, libro 15 de la cofradía de ánimas, p. 140v. 
expresada y tras varias consultas con algunos compañeros historiadores, podríamos aventurarnos a atribuir la obra a uno de los dos escultores que aprendieron de Martín de Andújar en Garachico durante el siglo Xvir y tras la partida de este a América que abrieron taller propio. Francisco Alonso de la Raya o Blas García Ravelo, quienes alcanzaron su plenitud escultórica por estas fechas, podrían ser los autores de la talla. Si bien alguno de sus elementos nos deja más dudas: mientras que la tosquedad de su forma es un punto a favor, la composición del pelo nos abre algunas cuestiones, ya que ese tipo de modelaje no es propio de estos autores. Lo que sí está claro es que no se trata de una obra alemana del siglo XVI, tal y como se propuso por algunos autores con anterioridad ${ }^{17}$.

Junto con el encargo de la imagen, también se ejecutó un trono dorado por valor de seiscientos ochenta reales ${ }^{18}$, así como la compra de diferentes artículos para el culto, como son cuarenta y dos reales de costo por dos báculos y una cruz para el altar dorada, una caldereta de plata que se compró «para pedir limosna por las puertas», una piedra de ara "para el altar de San Miguel», un frontal blanco, seis candelabros para el altar y una peana para delante del mismo. Además, se adquiere por valor de cuatrocientos treinta y dos reales un pendón de damasco amarillo que sirvió como distintivo de la confraternidad ${ }^{19}$. Quizás la elaboración de un pequeño altar, con frontal, peana, piedra de ara y candeleros, sirviera de forma provisional para colocar la imagen de san Miguel y establecer un punto fijo donde tener el centro de las celebraciones que en honor a las ánimas tenían lugar cada año en la parroquia.

La devoción a san Miguel Arcángel no es algo exclusivo de Los Realejos. Si ampliamos la vista al resto de la comarca nos damos cuenta de que la figura del santo estaba presente en la mayoría de las grandes parroquias donde existía una cofradía de ánimas. Un ejemplo sería el templo de San Juan Bautista de San Juan de la Rambla, donde en los inventarios también figura «una imagen del señor San Miguel con su peana y penachos de madera en el morreón del santo, todo dorado y estofado con una cinta verde de seda $»^{20}$. Lo mismo sucedía en la villa de La Orotava, donde en su parroquia matriz también existe una imagen de este santo de finales del siglo XVII, aunque en los inventarios aparece citada una talla anterior desde 1604, celebrándose fiesta en su honor desde al menos $1638^{21}$. También en la vecina parroquia de San Juan Bautista del Farrobo, donde en el retablo de ánimas se conserva una imagen del arcángel realizada en el siglo $\mathrm{XVIII}^{22}$.

17 Camacho y Pérez Galdós, Guillermo: Iglesias de la Concepción y Santiago Apóstol, Ayuntamiento de Los Realejos, Los Realejos, 1983, p. 19, citando bibliografía precedente.

${ }_{18}$ FPCRB, libro 15 de la cofradía de ánimas, p. $17 \mathrm{v}$.

19 FPCRB, libro 15 de la cofradía de ánimas, p. 18.

${ }^{20}$ FPSJB, libro 8 de la cofradía de ánimas, p. 10.

${ }^{21}$ Torres Luis [2017], p. 142.

${ }^{22}$ Lorenzo Lima, Juan Alejandro: Dolorosa del Santo Entierro. Historia de una devoción en La Orotava, Excmo. Ayuntamiento de La Orotava y Hermandad del Santo Entierro, La Orotava, 2016, p. 136. 


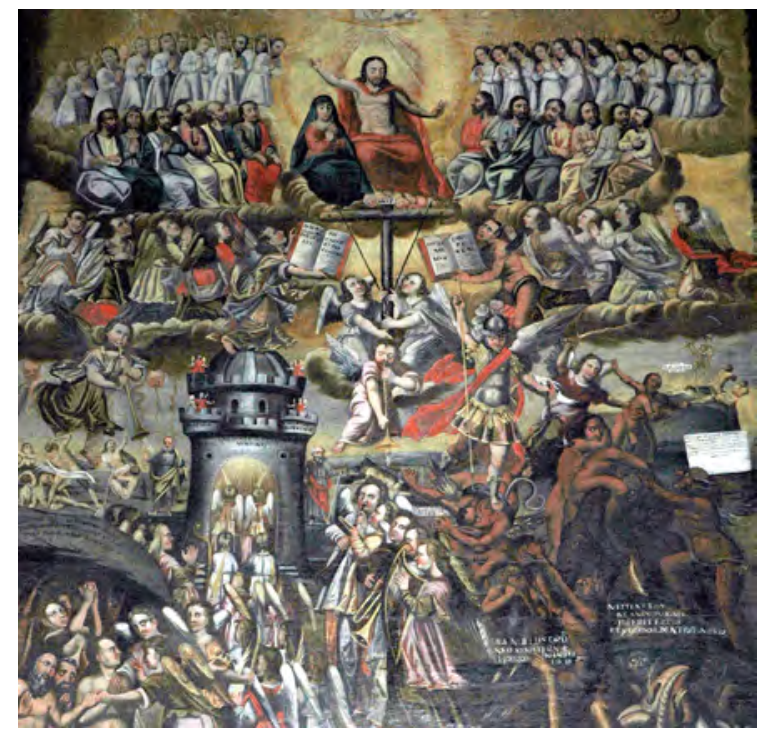

Fig. 3. Cuadro de ánimas. Anónimo tinerfeño, c. 1669, parroquia del Apóstol Santiago, Los Realejos.

Estamos, por tanto, durante las primeras décadas de estas instituciones, en las que no hay constancia de la existencia de cuadros de ánimas en ninguno de los dos templos. Sin embargo, la segunda mitad del siglo XviI trajo cambios en la parroquia del Apóstol Santiago. En 1669, bajo la mayordomía de Francisco Yanes Barroso, aparece un descargo de setecientos cincuenta y nueve reales por «un cuadro grande que se puso en el altar de las ánimas ${ }^{23}$. Sin lugar a dudas, se trata del lienzo que actualmente se conserva en el templo [fig. 3], en el que aparece en la parte superior la gloria celestial con la presencia de Cristo, rodeado por personajes con túnicas blancas, identificados como personas anónimas que han conseguido purgar sus pecados y gozan ya de la presencia divina. Además, los apóstoles y las santas mujeres completan este cuerpo superior. En la zona central, un castillo en el lado izquierdo representa las puertas del cielo flanqueado por ángeles con trompetas símbolo del anuncio del Juicio Final, por la que entran ángeles que acompañan a las almas hasta la gloria. Por la parte derecha, san Miguel envía al infierno a los condenados. La parte inferior del cuadro la cierra la representación del purgatorio en llamas, con la presencia de almas a la espera de partir al cielo ${ }^{24}$.

${ }^{23}$ Camacho y Pérez Galdós, Guillermo: Iglesias de la Concepción y Santiago Apóstol, Ayuntamiento de Los Realejos, Los Realejos, 1983, p. 50.

24 Estarriol Jiménez, Juana: La pintura de Cuadros de Ánimas en Tenerife, Las Palmas de Gran Canaria, 1981, pp. 27-28. 


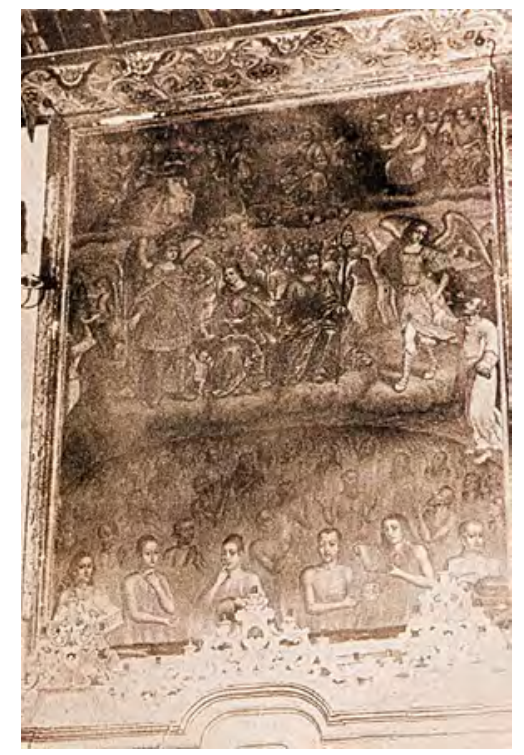

Fig. 4. Cuadro de ánimas (desaparecido). Seguidor de Cristóbal Hernández de Quintana, 1772-1779, parroquia de Nuestra Seńora de la Concepción, Los Realejos.

Resulta muy difícil establecer una atribución, ya que por cronología y tipología no lo podemos comparar con otro cuadro de la isla. Lo que sí está claro es que es una pintura de un artista local, de mediana destreza, que resuelve los problemas de perspectiva de una manera muy arcaica. Además, dejamos para más adelante un estudio iconográfico más profundo del mismo, ya que los textos, personajes y elementos tienen una lectura muy interesante que por motivos de espacio no podemos abordar ahora.

Para tener noticias del homónimo de ánimas en la parroquia de la Concepción, tenemos que avanzar prácticamente un siglo, ya que no es hasta la mayordomía de José Hernández Abreu, entre 1772 y 1779, cuando se encarga un gran cuadro de mil reales de coste [fig. 4] más otros cuarenta y ocho reales que se gastaron en colocarlo ${ }^{25}$. Estamos hablando de una gran diferencia temporal entre ambas parroquias, lo que demuestra sin duda la escasez de recursos económicos de la cofradía del Realejo de Abajo con respecto al Realejo de Arriba, y la cantidad de ańos que debieron pasar para reunir el dinero necesario para afrontar el costo elevado que suponía un cuadro de tal dimensión. Con respecto a su formato, el lienzo se representaba dividido en tres partes. En la superior, la gloria celestial presidida

25 Camacho y Pérez Galdós, Guillermo: Iglesias de la Concepción y Santiago Apóstol, Ayuntamiento de Los Realejos, Los Realejos, 1983, p. 19. 
por la Trinidad y una serie de santos y santas que los cortejan. En la parte central, san José invita a contemplar el juicio que están realizando en el lado izquierdo el arcángel Miguel y la Virgen. Miguel sostiene la balanza para que la Virgen pese las almas, mientras que en el lado derecho otro ángel rescata un alma del purgatorio, escena que conecta directamente con el cuerpo inferior, que representa ese trance. Se trata, con toda exactitud, de una copia realizada del gran lienzo que el maestro Cristóbal Hernández de Quintana [1651-1725] pintó para la cofradía de ánimas de la antigua parroquia de Los Remedios, actual catedral de La Laguna, durante el siglo $\mathrm{XVII}^{26}$. Si bien el simulacro del Realejo Bajo, al igual que ocurre con el de la iglesia de Santa Úrsula del municipio del mismo nombre, no podemos adjudicarlo al maestro Quintana ya no solo por la cronología -fueron ejecutados casi medio siglo después de la muerte del artista-, sino por su pintura más simple y con más problemas de ejecución, por lo que estamos, pues, ante un artista de segunda fila, seguidor de los esquemas del maestro. Erróneamente, se ha atribuido el lienzo de Santa Úrsula a un supuesto pintor llamado Domingo Lorenzo ${ }^{27}$; sin embargo, consultando el libro de la institución nos hemos percatado de que el personaje fue el mayordomo que encargó la obra en el período que ejerció su mayordomía (1756$1760)^{28}$ y no su pintor como hasta ahora se creía. Aun así, planteamos que ambos lienzos fueron realizados por un mismo artista, seguidor del propio Quintana, que reprodujo su obra de la antigua parroquia de Los Remedios de La Laguna en los lienzos del Realejo Bajo y Santa Úrsula.

Una vez colocados en los templos los grandes lienzos de ánimas, el esfuerzo de las cofradías de ambos Realejos se va a centrar en la construcción de retablos que los alberguen. Como es normal, la parroquia del Apóstol Santiago, que adquirió el cuadro en 1669, sería la primera en colocar un retablo. Así deja constancia de la idea el mayordomo, Lucas Padrón de Andrada, ese mismo año cuando asegura que:

Dicha cofradía necesita de un altar de ánimas por no haberlo en dicha parroquial donde se ponga un retablo de pintura que dicha cofradía tiene para mayor utilidad de dicha cofradía y provecho de las benditas ánimas del purgatorio ${ }^{29}$.

Es entonces en 1673 cuando se gastan doscientos siete reales y tres cuartos en hacer y dorar un marco para el lienzo, acometiendo así una primera obra para adecentar el conjunto, que se vio completado con la hechura de un altar de madera con peana, además de comprar dos frontales, manteles, candeleros, tablas del canon y cruz $^{30}$. Sin embargo, este retablo no es el que llegó hasta nuestros días, ya que a

y 149.

27 Estarriol Jiménez, Juana: La pintura de Cuadros de Ánimas en Tenerife, Las Palmas de Gran Canaria, 1981, p. 17, con bibliografía precedente.

${ }_{28}$ AHDLL, FPSU, libro 1 de la cofradía de ánimas, p. 89v.

29 FPASRA, libro 4 de la cofradía de ánimas, p. 50.

${ }^{30}$ FPASRA, libro 4 de la cofradía de ánimas, pp. 52v-53. 
mediados del siglo XVIII, concretamente en 1746, aparecen registrados donativos y compras de madera adelantada para hacer uno nuevo ${ }^{31}$, por lo que la confraternidad se estaba planteando ya por esas fechas la realización de un nuevo mueble que se vio culminado unas décadas después, en 1776, cuando aparecen descargos en madera "para el retablo que se está haciendo" y pagos «dados al carpintero en cuenta de trescientos que cuesta la hechura ${ }^{32}$. Al igual que sucedió con el primer altar, la obra quedó en madera vista, hasta que años después, en 1790, hay justificaciones de compra de materiales y gastos de trabajo "para darle yeso al retablo" ${ }^{33}$, como estuco preparador para el dorado, que consta en las cuentas del año $1794^{34}$. Este simulacro, que sí es el que conservamos hoy, es muy simple en sus formas, con dos grandes estípites que enmarcan el cuadro coronado por una cornisa y remate en madera calada flanqueado por dos jarrones. La policromía es sencilla: predominan los colores grisáceos y dorados, más marcados en el frontal y estípites. En la parte inferior, bajo el cuadro, se abren tres nichos presididos por san Pedro Papa, escultura salida de la gubia de Sebastián Fernández Méndez ${ }^{35}$, cuya hornacina entra en el cuadro obligando a cortarlo en torno a estas fechas, debido a un acuerdo llegado entre la cofradía de ánimas y la de San Pedro Apóstol ${ }^{36}$.

En el caso de la parroquia de la Concepción, el retablo se coloca en la misma fecha que el cuadro, es decir, en el período de mayordomía de José Hernández Abreu, que abarca desde 1772 a 1779 , con un coste que ascendió a quinientos ochenta y dos reales, aunque no se policroma hasta la mayordomía siguiente, regida por Juan Pérez Valladares durante los años 1781 a 1788 y con un costo que se elevó hasta los mil trescientos sesenta y siete reales ${ }^{37}$.

La estructura del retablo la podemos dividir en dos partes: el cuerpo superior, presidido por el cuadro, es de una estructura simple formada por el marco del mismo y un doselete de madera con guardamalleta que sirve para coronarlo. Mientras, el cuerpo inferior está formado por tres calles, separadas por estípites y un solo cuerpo coronado por cornisa que se trunca en el centro por el remate de la hornacina de la calle principal, donde se colocó la talla de san Miguel Arcángel. Los aletones laterales y las cartelas superiores preparadas para la cera, de madera calada, coronan la parte inferior desde donde arranca el cuadro. Años después, en 1790, se gastaron diez reales en pintar las imágenes de san Juan Nepomuceno y san Blas que se colocaron, a modo de esculturas, en las calles laterales del cuerpo inferior y que recuerdan a los lienzos de san Pedro y san Pablo que se encargaron por las mismas

31 FPASRA, libro 4 de la cofradía de ánimas, p. 79.

${ }^{32}$ FPASRA, libro 4 de la cofradía de ánimas, p. 90.

${ }^{33}$ FPASRA, libro 4 de la cofradía de ánimas, p. 94.

${ }^{34}$ FPASRA, libro 4 de la cofradía de ánimas, p. 98.

35 Camacho y Pérez Galdós, Guillermo: Iglesias de la Concepción y Santiago Apóstol, Ayuntamiento de Los Realejos, Los Realejos, 1983, p. 51.

36 FPASRA, libro 5 de la cofradía de San Pedro Apóstol, p. 94.

37 Camacho y Pérez Galdós, Guillermo: Iglesias de la Concepción y Santiago Apóstol, Ayuntamiento de Los Realejos, Los Realejos, 1983, p. 19. 
fechas para la ermita de Nuestra Señora del Amparo en Icod de los Vinos y que siguen los esquemas del maestro Cristóbal Afonso ${ }^{38}$. La policromía del conjunto, de ricos colores y estofado, recuerda otros simulacros que son muy repetidos por la geografía insular, con un ornato común de pan de oro y colores que reprodujo el propio Cristóbal Afonso ${ }^{39}$, no descartando su mano en el altar que estudiamos.

En los inventarios de las cofradías de ambas parroquias se hace referencia a los túmulos. En la parroquia de la Concepción, a finales de la década de los ochenta aparecen reflejados una serie de gastos para la construcción de un túmulo para la fiesta de noviembre ${ }^{40}$. Se trataba de una gran estructura efímera que se montaba en el centro del templo para las honras fúnebres de algún destacado personaje, como podría ser el rey o un príncipe, así como para las novenas de ánimas del mes de noviembre. Desgraciadamente, estos grandes monumentos quedaron es desuso perdiéndose la inmensa mayoría de ellos, ya que eran de materiales endebles, como el papel o cartón, rescatándose tan solo la del vecino pueblo de San Juan de la Rambla, el cual se encuentra montado en una de las capillas laterales, aunque data de la segunda mitad del siglo xix y es de materiales más duraderos.

\section{CULTOS}

Las celebraciones de las dos cofradías de ánimas de Los Realejos giraban en torno a dos ejes centrales a lo largo del año: el primero, como ya hemos comentado, fue el día del Arcángel. El 29 de septiembre se celebraba en ambos templos una función solemne a la que asistían las confraternidades, que acababa con una procesión de la imagen solo en el caso de la parroquia de la Concepción ${ }^{41}$. En el caso del templo de Santiago, que no haya referencias a estos trayectos no quiere decir que no existiesen. El segundo eran los cultos que en el mes de noviembre se organizaban en torno a las ánimas del purgatorio. Se establecía una novena de Ánimas los nueve primeros días de mes con rezos, vigilias y procesiones claustrales todos los días, además de las eucaristías ofrecidas por el eterno descanso de los difuntos. Asimismo, también se reservaron todos los lunes del año para una celebración organizada por la cofradía en la que, aparte de la pertinente misa cantada, se rezaban responsos por el eterno descanso de los difuntos. Estos cultos sí eran habituales en las dos confraternidades que se esmeraban en buscar predicadores, adornar el templo y comprar cera para alumbrar el altar. El esplendor de los cultos dependía de la cantidad de caudal que tuvieran las cofradías para ese año. Para ello, las fuentes de ingreso eran fundamentales para su sostenimiento. Estas dependían de tres fuentes directas: la

38 En un estudio que está próximo a ver la luz, se está trabajando sobre la posible autoría de estos lienzos de Icod por parte de Afonso o uno de sus seguidores.

39 Lorenzo Lima, Juan Alejandro: «Retablo y discurso estético en Canarias a finales de la época Moderna», Revista Vegueta, vol. 17, 2017, pp. 455-492.

40 FPCRB, libro 15 de la cofradía de ánimas, p. 34.

${ }^{41}$ FPCRB, libro 15 de la cofradía de ánimas, p. 115v. 
primera era la cuota que pagaban los hermanos que pertenecían a la confraternidad. Como es lógico, cuanto mayor número de hermanos, mayor cantidad de ingresos. La segunda fuente era de las pedidas que se realizaban por las ánimas por las calles de ambos pueblos. Para esas limosnas, las cofradías poseían una caldereta de plata y una campanilla que se iba tocando por la calle a medida que iban, puerta por puerta, pidiendo ${ }^{42}$, llegando incluso, en el caso de la parroquia del Realejo Bajo, a pedir limosna hasta Icod el Alto ${ }^{43}$, lo que confirma que abarcaban un gran territorio y que apostaban por esta fuente de ingresos que les garantizaba caudal para afrontar gastos. La tercera fuente común, quizás la más importante, era la ingresada por el alquiler del paño de difuntos. Este paño, de color negro, era colocado sobre el cadáver de la persona fallecida a la que se le realizaba el oficio y la familia debía pagar una suma indeterminada para poder colocárselo, devolviéndolo posteriormente tras la exhumación del cadáver. El canon establecido por el alquiler variaba según la zona, aunque no podemos establecer el precio unitario porque en las cuentas de cada institución aparece reflejada la suma de los alquileres del año, algo que variaba, como es lógico, según el número de entierros. La parroquia del Apóstol Santiago tuvo una fuente de ingresos más que no hemos encontrado en otra institución del valle. Se trata de alquileres de "túnicas de disciplinantes con sus azotes y capillos» ${ }^{44}$ para los hermanos que quisieran flagelarse durante el novenario, algo que habíamos visto en otras cofradías, sobre todo en Semana Santa ${ }^{45}$, pero no en las instituciones de ánimas, lo que supone un ingreso extra para la institución del Realejo de Arriba.

Otros gastos de los cultos que pueden llamarnos la atención pueden ser el pago a «los muchachos para doblar la noche de finados» ${ }^{46}$, o los descargos de aceite para "la lámpara del cementerio " ${ }^{47}$, la cual debía estar siempre encendida por cuenta de la cofradía. También, un gasto en el que coinciden ambas instituciones es el de «hacer dos tablitas para avisar a los fieles en las puertas de la iglesia los días en que se saca ánima ${ }^{48}$. Se trataba de una especie de tablón de anuncios donde se avisaba a los fieles que entraban al templo a la eucaristía de la mañana que ese día tocaba pedida por la calle.

${ }^{42}$ FPCRB, libro 15 de la cofradía de ánimas, p. 18.

${ }_{43}$ FPCRB, libro 15 de la cofradía de ánimas, p. 34.

${ }^{44}$ PRASRA, libro 4 de la cofradía de ánimas, p. 44v.

${ }^{45}$ Hernández Abreu, Pablo: «La cofradía de la Misericordia de Realejo Bajo. Nuevos apuntes históricos", en La Prensa, revista semanal de El Día, Santa Cruz de Tenerife, 11 de noviembre de 2017, pp. 1-3.

46 FPASRA, libro 4 de la cofradía de ánimas, p. 46.

47 FPASRA, legajo 1 de la cofradía de ánimas, cuentas del año 1876, sf.

48 FPCRB, libro 15 de la cofradía de ánimas, p. 66. 


\section{DECADENCIA}

El siglo XIX trajo consigo las leyes desamortizadoras, que afectaron a la Iglesia con la supresión de muchos conventos y cofradías lo que mermó la riqueza de las instituciones eclesiásticas.

La cofradía de ánimas de Realejo Bajo se vio afectada por estas leyes. El libro que se conserva en su fondo parroquial acaba en 1805, aunque hace referencia a que las nuevas cuentas se anotarán en un nuevo texto ${ }^{49}$. Sin embargo, la desaparición de ese libro y la inexistencia de nuevos datos de la institución nos lleva a pensar en su desaparición en la década de los treinta del mismo siglo, algo que también sucedió con otras instituciones de la parroquia ${ }^{50}$.

Por el contrario, la cofradía de la parroquia del Realejo de Arriba nos deja más dudas con respecto a su posible desaparición, ya que su libro de cuentas acaba en 1805 con un gran número de páginas siguientes en blanco. Es decir, al contrario de lo que ocurre con la parroquia de la Concepción, si el libro de cuentas acaba, es muy probable que se siga escribiéndose en un nuevo libro. Sin embargo, en Realejo Alto, las cuentas acaban de una manera precipitada, lo que nos lleva a pensar que la cofradía se vio interrumpida en esa fecha. Sea como fuere, lo que sí es cierto es que esas cuentas se retoman posteriormente en 1870 en forma de legajos, y llegan hasta 1944, por lo que sí debemos señalar esa fecha como la de la desaparición definitiva de la institución, más de un siglo después de su homónima del Realejo Bajo.

Los vestigios de la cofradía han pervivido en la parroquia de Santiago, con su imponente retablo y la imagen de san Miguel, testigo fiel de un pasado esplendoroso. Por desgracia, no podemos decir lo mismo de la parroquia de la Concepción, donde el incendio del 5 de noviembre de 1978 destruyó casi todos los testigos de la antigua cofradía. Tan solo pudieron rescatarse de entre los escombros las antiguas pesas de la imagen de san Miguel, que, como vimos, habían sido adquiridas en el siglo XviII. Por suerte, tras la reapertura del templo, se ha podido reconstruir su altar gracias a la generosidad del pintor Eleuterio Garrido Luceño, quien dona el gran lienzo que lo preside en 1998 y posteriormente, en el año 2010, los carpinteros José y Manuel Hernández Siverio, junto al grupo de jóvenes de la parroquia y al propio pintor, construyen el nuevo retablo que hoy en día se levanta en el costado sur del templo.

Recibido: 15-03-2018, ACEPTAdo: 10-04-2018

49 FPCRB, libro 15 de la cofradía de ánimas, p. 153.

50 Hernández Abreu, Pablo: «La cofradía de la Misericordia de Realejo Bajo. Nuevos apuntes históricos», en La Prensa, revista semanal de El Día, Santa Cruz de Tenerife, 11 de noviembre de 2017, pp. 1-3. 